\title{
Front Line Demonstration: A Technology Tool to Enhance the Millets Yield of North Karnataka
}

\author{
P. Ashoka ${ }^{1 *}$, P. Priya ${ }^{2}$ and Sarojani J. Karakkannavar ${ }^{3}$ \\ ${ }^{1}$ ICAR-Krishi Vigyan Kendra, Ranebennur taluk, Haveri District- 581 11, India \\ ${ }^{2}$ Department of Agronomy, College of Agriculture, \\ Hanumanamatti, Ranebennur taluk, Haveri District- 581 11, India \\ ${ }^{2}$ Department of Food Science and Nutrition, \\ College of Community Sciences, Dharwad - 580 005, India \\ *Corresponding author
}

\section{Keywords}

Millets, Yield gap,

Front line

demonstration, improved practice,

Farmers' practice

Article Info

Accepted:

20 May 2020

Available Online:

10 June 2020

\begin{abstract}
A B S T R A C T
Small millets are more nutritious and have a lower glycemic index than rice and wheat, but factors like lack of improved varieties, agronomical packages and practices as well as unorganized seed system are constraining production and productivity. Therefore, the present study was carried out to know the yield gaps between improved practices and farmers' practices under Frontline demonstration on little millet and foxtail millet were carried out by ICAR-Krishi Vigyan Kendra, Hanumanamatti, Haveri district of North Karnataka to assess the impact of adopting improved package of practices over farmers' practice on the yield and economics of millets during kharif season from 2013 to 2019. Higher yield of little millet was recorded under improved practices which were ranged from 13.60 to 18.00 q. ha ${ }^{-1}$ which was 18.70 to 28.57 per cent higher than farmers' practice. Similar trend was noticed in foxtail millet which was showed 14.50 to 21.00 per cent higher grain yield over farmers' practice during all the five years. The average technological gap for grain yield in little millet and foxtail millet ranged from 7.00 to $15.00 \mathrm{q}$. ha ${ }^{-1}$ and 4.00 to $12.30 \mathrm{q}$. ha ${ }^{-1}$, respectively over the five years. Highest gross return of Rs. $43,484 \mathrm{ha}^{-1}$, Rs. $35,656 \mathrm{ha}^{-1}$ of net return with highest $\mathrm{B}: \mathrm{C}$ ratio of 5.56 were obtained across the five years for millets under improved practices as compared to farmers' practice.
\end{abstract}

\section{Introduction}

The environmental, social and economic challenges of 21 st century like climate change, water scarcity, increasing world population, rising food prices and other socioeconomic impacts are expected to generate a great threat to agriculture and food security worldwide, especially for the poorest people who live in arid and sub-arid regions as stated by Saleh et al., (2013). Therefore, there is need of alternative crops that can resist changing environmental condition and provide nutritive food source.

Ushakumari et al., (2004) stated that the millets are considered as crop of food security because of their sustainability in adverse agro-climatic conditions. Small millets are small sized grains and grown in different 
regions of the world from east to west because they share a set of characteristics which make them unique amongst cereals due to their productivity and short growing season under dry, high temperature conditions and can survive in areas with as little as $300 \mathrm{~mm}$ or less of seasonal rainfall. As millets are photo insensitive and have shorter growing season and low moisture demand. In kharif season millets are one of the major crops besides the maize and rice in many parts of Northern districts of Karnataka.

Millets are major food sources for millions of people, especially those who live in hot and humid areas of the world. They fit in well with mixed cropping system. They not only provide nutritious food for the people but are also a source of fodder for the cattle. There has been large-scale reduction in the cultivation of these small millets owing to the impacts of the green revolution. There is declining production of these small millets with each passing year.

However, efforts to popularise the cultivation of these millets in order to conserve genetic diversity as well as to utilize the marginal and arid lands are being taken up. In this regard various high yielding varieties for the small millet crops have been released and are being cultivated. The All India Co-ordinated Research Project on small millets was initiated during 1992 at Hanumanamatti and is continuing till date. A repertoire of local land races of small millets were collected and evaluated in the station for various characters.

Many promising varieties were identified and were released after multi-location trial. These varieties along with agronomic practices were popularised among the farming community of the district through Front Line Demonstrations and sale of quality seeds both by KVK and ARS, Hanumanamatti. Keeping the facts in view, importance of FLD, the
KVK, Haveri, conducted demonstration on millets crop in farmer's field under Rainfed situation of kharif season from 2013 to 2019. The objectives were framed for the study as follows, to compare the yield levels of local check (farmer practices) and Front Line demonstration. And also to workout the economic feasibility of the crop (Front Line demonstration v/s local check)

\section{Materials and Methods}

Front Line Demonstration on assess the impact of adopting improved package of practices over farmers' practice on the yield and economics of millets yield. An attempt to study the impact of this transfer of technology through participatory approach on the economics of the district was made. The study was conducted in Haveri district of Karnataka, which comes under Agro-climatic Zone -8 i.e. Northern Transitional Zone. All the seven block of the haveri district were considered for the study.

The sample for the study was 158 randomly selected respondents, which comprised of 73 Little millet growers and 85 foxtail millet growers. The list of all the beneficiaries was organised village wise and year wise and then the required sample was randomly selected for the study. Front line demonstrations (FLDs) undertaken by the KVK in Haveri District to popularise the improved production practices of small millets have resulted in better performance not only in increasing the yield levels of the crops but also in increasing the utility of these crops for home consumption. The study to assess the economic impact of the FLDs on the district economic scenario revealed worth noticing impacts. The demonstration of improved technology was taken in area of 0.05 ha of each farmer. These varieties were compared with farmers practice i.e. treated as a control. The result was compared with the full 
package of practice. The primary data on output of millets yield were collected from the selected farmers in FLD plots, besides the data on local practices commonly adopted by the farmers of this region were also collected with the help of interview schedule and presented in term of percentage and qualitative data was converted in to quantitative form and expressed in term of percent increased yield was calculated by the using formula

The average yield of each FLD and farmers practice, cost of cultivation, gross return, net return and benefit cost ratio (B: $\mathrm{C}$ ratio) was taken for interpretation of the results. The extension gap, technology gap and technology index were calculated using the following formula as suggested by Samui et al., (2000).

Extension gap $=$ Demonstration yield - Local check yield

Technology gap $=$ potential yield Demonstration yield

Technology index $=$ Potential yield Demonstration yield x 100/Potential Yield

$\%$ Increase over farmers practice $=\frac{\text { Improved practice }- \text { Framers practice }}{\text { Farmers practice }}$

The yield data were collected for with the two recommended and one control plots (farmer practice). Their feasibility and economics variability were accessed the trial was also envisaged with four fundamental assumption

When the technology is not acceptable for the farmer in it recommended form and needs minor modification, refinement or change.

It needs the integration of related indigenous knowledge of the farmers with the scientific recommendation in the process of refinement or modification, moreover the refinement or modification is a continuous process in the lake of available technological option specific to each microenvironments.

The collaboration of farmers who has been experimenting on their own to evolve solutions to the constraints, in their farm and of the extension system which is vital in the process of technology development.

The technology or practices generation through Front Line Demonstrations become farmer's recommendation comprising a basket of after natures and as the most appropriate to solve problem. Keeping above in view the Front Line Demonstrations were executed. There were performance indicator and economic indicates considered to execute the trial.

\section{Results and Discussion}

During the FLDs, the problems faced by farmers in small millet production were documented and the perusal data is presented in Table 1. The major problems faced by farmers lack of high yielding varieties (86.19 $\%)$, timely availability of quality seeds (79.24 $\%)$, marketing (73.34 \%), low technical knowledge $(70.68 \%)$, use of higher seed rate $(67.30 \%)$ while diseases like grain smut in barnyard millet and Cercospora leaf spot in finger millet also observed by farmers $(37.67 \%)$ as a major grain production constraint followed by insect $(24.42 \%)$.

However the other production constraints observed during FLDs are limited possibility of mechanization to reduce the drudgery associated with production and post-harvest operations, food of marginalized communities, although it is consumed by the majority of households in the mid and high hills regions in varying quantity, irrespective of ethnicity and lack of awareness on the nutrient composition and value of small millets on human health; consequently there is a low rate of consumption especially among the younger generation. 
Singh et al., (2017) also conducted a frontline demonstration on wheat in Rudraprayag District of Uttarakhand and reported almost similar production constraints. Dhruw et al., (2012) has also reported similar constraints in maize

\section{Grain and fodder yield}

Grain yield and fodder yield of little millet and foxtail millet under improved practices and farmers' practices are presented in the Table 1 and Table 3, which clearly elucidated that the use of high yielding varieties helped for boosting the productivity of foxtail millet as well as little millet under rainfed conditions of Haveri district.

The average grain yield of little millet under improved practices ranged from 13.60 to $18.00 \mathrm{q} \mathrm{ha}^{-1}$ which is 18.70 to 28.57 per cent higher than farmers' practice.

Similar trend was also observed in foxtail millet, which showed 14.50 to 21.00 per cent grain yield advantage over farmers' practice during five years. Thakur et al., (2017) reported 140.12 per cent higher grain yield of finger millet under improved practices than farmers' practices whereas, 53.5 to 61.3 per cent higher yield in finger millet and 53.5 to 101.8 per cent more yield of barnyard millet under improved variety over local variety was recorded by Yadav and Yadav (2009) in Himalayan hills.

\section{Technology gap}

The average technological gap for grain yield in little millet ranged from 7.00 to $15.00 \mathrm{q} \mathrm{ha}^{-}$ ${ }^{1}$ and 4.00 to $12.30 \mathrm{q} \mathrm{ha}^{-1}$ in finger millet over the five years. The higher technological gap may be attributed mainly due to the uneven distribution of rainfall, variations in soil fertility and cultivation on marginal lands and local specific crop management problems faced in order to harness the yield potential of specific crop cultivars under demonstration plots. The average technology gap $9.91 \mathrm{q} \mathrm{ha}^{-1}$ for finger millet was reported by Thakur et al., (2017) and Dhaka et al., (2010) in maize and Joshi et al., in wheat. Vedna et al., (2007) stated that the location specific crop management is the need of hour to bridge the gap in potential and demonstration yields.

Table.A List of production constraints and their rank given by farmers

\begin{tabular}{|l|l|c|c|}
\hline SI no. & Major constraints & Percentage & Rank \\
\hline $\mathbf{1}$ & Lack of high yielding varieties & 86.19 & I \\
\hline $\mathbf{2}$ & Timely availability of quality seeds & 79.24 & II \\
\hline $\mathbf{3}$ & Marketing & 73.34 & III \\
\hline $\mathbf{4}$ & Low technical knowledge & 70.68 & IV \\
\hline $\mathbf{5}$ & Use of higher seed rate & 67.30 & V \\
\hline $\mathbf{6}$ & Diseases of small millets & 37.67 & VI \\
\hline $\mathbf{7}$ & Insect-pests of small millets & 24.42 & VII \\
\hline
\end{tabular}


Table.1 Impact of improved and farmers practices on grain yield of little millet under frontline demonstration

\begin{tabular}{|c|c|c|c|c|c|c|c|c|c|c|c|}
\hline \multirow[t]{2}{*}{ Year } & \multirow[t]{2}{*}{ Technology demonstrated } & \multirow{2}{*}{$\begin{array}{c}\text { Block } \\
\text { Village }\end{array}$} & \multirow{2}{*}{$\begin{array}{l}\text { No of } \\
\text { Demo. }\end{array}$} & \multirow{2}{*}{$\begin{array}{l}\text { Area } \\
(\mathbf{q} / \mathbf{h a})\end{array}$} & \multicolumn{3}{|c|}{ Grain Yield (q/ha) } & \multirow{2}{*}{$\begin{array}{c}\% \\
\text { increase }\end{array}$} & \multicolumn{3}{|c|}{ Grain Yield (q/ha) } \\
\hline & & & & & Demo & Avg. & Check & & TG & EG & TI \\
\hline 2013-14 & $\begin{array}{l}\text { Popularization of Suskshema } \\
\text { variety of Little Millet }\end{array}$ & sangur & 25 & 10 & 18.20 & 13.20 & 10.50 & 25.70 & 7.00 & 7.50 & 38.88 \\
\hline 2015-16 & $\begin{array}{l}\text { NFMS Demonstration of } \\
\text { variety DHLM-36-3 }\end{array}$ & Mugali & 20 & 0.4 & 17.50 & 15.20 & 12.5 & 28.57 & 7.50 & 5.00 & 30.00 \\
\hline 2017-18 & $\begin{array}{l}\text { DHLM-36-3 Variety gives } \\
\text { high yield of 15-20/ha with } \\
\text { good fodder yield }\end{array}$ & Basapur & 18 & 7.2 & 13.6 & 15.53 & 12.58 & 23.44 & 7.00 & 10.8 & 28.00 \\
\hline 2018-19 & $\begin{array}{l}\text { DHLM-36-3 for higher yield } \\
\text { and income }\end{array}$ & $\begin{array}{l}\text { S.Sompu } \\
\mathrm{r}\end{array}$ & 10 & 4.0 & 15.85 & 14.17 & 12.5 & 18.71 & 15.00 & 6.00 & 60.00 \\
\hline
\end{tabular}

*TG-Technical gap EG-Extension gap TI-Technology index

Table.2 Economic analysis of little millet under frontline demonstration

\begin{tabular}{|c|c|c|c|c|c|c|c|c|}
\hline \multirow[t]{2}{*}{ Year } & \multicolumn{3}{|c|}{ Demonstration } & \multicolumn{3}{|c|}{ Control/check } & \multicolumn{2}{|c|}{ B:C ratio } \\
\hline & $\begin{array}{c}\text { Cost of } \\
\text { Cultivation } \\
\text { (Rs/ha) }\end{array}$ & $\begin{array}{c}\text { Gross } \\
\text { return } \\
\text { (Rs/ha) }\end{array}$ & $\begin{array}{c}\text { Net return } \\
\text { (Rs/ha) }\end{array}$ & $\begin{array}{c}\text { Cost of } \\
\text { Cultivation } \\
\text { (Rs/ha) }\end{array}$ & $\begin{array}{c}\text { Gross return } \\
\text { (Rs/ha) }\end{array}$ & $\begin{array}{c}\text { Net return } \\
\text { (Rs/ha) }\end{array}$ & Demonstration & Check \\
\hline 2013-14 & 11250 & 33000 & 21750 & 10700 & 26250 & 15550 & 2.93 & 2.45 \\
\hline 2015-16 & 4721 & 20096 & 15379 & 4717 & 14976 & 10258 & 3.17 & 2.65 \\
\hline 2017-18 & 7825 & 43484 & 35659 & 7800 & 35224 & 27424 & 5.56 & 4.52 \\
\hline 2018-19 & 16098 & 44380 & 28282 & 14950 & 37380 & 22430 & 2.76 & 2.50 \\
\hline
\end{tabular}


Table.3 Impact of improved and farmers practices on grain yield of foxtail millet under frontline demonstration

\begin{tabular}{|c|c|c|c|c|c|c|c|c|c|c|c|}
\hline \multirow[t]{2}{*}{ Year } & \multirow[t]{2}{*}{ Technology demonstration } & \multirow{2}{*}{$\begin{array}{l}\text { Name of } \\
\text { the Block/ } \\
\text { Village }\end{array}$} & \multirow{2}{*}{$\begin{array}{l}\text { No of } \\
\text { Demo }\end{array}$} & \multirow{2}{*}{$\begin{array}{l}\text { Area } \\
\text { (ha) }\end{array}$} & \multicolumn{3}{|c|}{ Grain Yield (q/ha) } & \multirow{2}{*}{$\begin{array}{c}\% \\
\text { increase }\end{array}$} & \multicolumn{3}{|c|}{ Grain Yield (q/ha) } \\
\hline & & & & & Demo & $\begin{array}{l}\text { Avera } \\
\text { ge }\end{array}$ & TG & & TG* & EG* & TI \\
\hline 2013-14 & $\begin{array}{l}\text { Popularization of HMT-100-1 } \\
\text { variety of Foxtail millet }\end{array}$ & Sangur & 24 & 10 & 21.00 & 17.10 & 13.00 & 30.76 & 4.00 & 4.00 & 16.00 \\
\hline 2015-16 & $\begin{array}{l}\text { ICM in Foxtail millet variety } \\
\text { DHFT-109-3 }\end{array}$ & $\begin{array}{l}\text { Mugali, } \\
\text { Timmapur }\end{array}$ & 17 & 0.4 & 17.00 & 15 & 14.00 & 21.05 & 8.00 & 2.00 & 32.00 \\
\hline 2016-17 & $\begin{array}{l}\text { Demonstration of foxtail } \\
\text { millet variety DHFT-109-3 }\end{array}$ & Basapur & 10 & 0.6 & 16.00 & 15.2 & 11.75 & 21.07 & 9.00 & 0.80 & 39.20 \\
\hline 2017-18 & $\begin{array}{l}\text { Demonstration of foxtail } \\
\text { millet variety DHFT-109-3 }\end{array}$ & Basapur & 18 & 7.2 & 14.50 & 12.70 & 11.85 & 22.36 & 12.3 & 1.80 & 42.00 \\
\hline 2018-19 & $\begin{array}{l}\text { DHFT-109-3 for higher yield } \\
\text { and income }\end{array}$ & Attigeri & 15 & 0.6 & 17.12 & 12.45 & 12.50 & 37.0 & 7.88 & 4.67 & 31.52 \\
\hline
\end{tabular}

*TG-Technical gap EG-Extension gap, TI-Technology index

Table.4 Economic analysis of foxtail millet under frontline demonstration

\begin{tabular}{|c|c|c|c|c|c|c|c|c|}
\hline \multirow[t]{2}{*}{ Year } & \multicolumn{3}{|c|}{ Demonstration } & \multicolumn{3}{|c|}{ Control/check } & \multicolumn{2}{|c|}{ B:C ratio } \\
\hline & $\begin{array}{c}\text { Cost of } \\
\text { Cultivation } \\
\text { (Rs/ha) }\end{array}$ & $\begin{array}{c}\text { Gross } \\
\text { return } \\
\text { (Rs/ha) }\end{array}$ & $\begin{array}{l}\text { Net return } \\
\text { (Rs/ha) }\end{array}$ & $\begin{array}{c}\text { Cost of } \\
\text { Cultivation } \\
\text { (Rs/ha) }\end{array}$ & $\begin{array}{l}\text { Gross return } \\
\text { (Rs/ha) }\end{array}$ & $\begin{array}{l}\text { Net return } \\
\text { (Rs/ha) }\end{array}$ & Demo & Check \\
\hline 2013-14 & 11250 & 25500 & 14250 & 10700 & 19500 & 8800 & 2.26 & 1.80 \\
\hline 2015-16 & 4461 & 22755 & 18294 & 45791 & 15564 & 10985 & 5.20 & 3.40 \\
\hline 2016-17 & 4800 & 27911 & 23111 & 4800 & 20938 & 16138 & 5.81 & 4.36 \\
\hline 2017-18 & 7600 & 43500 & 35900 & 7500 & 35550 & 28050 & 5.72 & 4.74 \\
\hline 2018-19 & 15598 & 5130 & 35752 & 14550 & 37350 & 22800 & 3.29 & 2.57 \\
\hline
\end{tabular}




\section{Extension gap}

The average extension gap for little millet yield was found to be 5.00 to $10.80 \mathrm{q} \mathrm{ha}^{-1}$ while extension gap for foxtail millet yield ranged from 2.00 to $4.00 \mathrm{q} \mathrm{ha}^{-1}$ over five years. The higher extension yield gap due to lack of awareness for the adoption of improved farm technologies by the farmers indicating that there is a strong need to aware and motivate the farmers for adoption of improved farm technologies in little millet and foxtail millet over existing local practices.

Choudhary et al., (2009) argued that the refinement in the local farmers' practices for higher adoption of location specific generated farm technology for sustaining crop productivity is another option open for the research scientists whereas, the successful development, dissemination and adoption of improved technologies for small-holders depend on more than careful planning of research and the use of appropriate methodologies in extension as stated by Jeengar et al., (2006).

\section{Technology index}

The average technology index was quite higher in both the crops over five years as indicated by Table 1 and 2. The technology index calculated for little millet showed higher value that ranged from 28.00 to 60.00 per cent for grain yield. However, similar trend were also observed in foxtail millet that varied from 16.00 to 42.00 per cent for grain yield over the five years under reined conditions.

Poor field establishment at early vegetative stage due to water stress under rainfed farming with uneven rainfall distribution, long dry spell and increasing pressure of diseases and insect pests are the possible reason for poor yields causing higher technology index in both the crops. Technology index indicates the feasibility of generated farm technologies in the farmers' fields under existing agro-climatic conditions as stated by Vedna et al., (2007) and Choudhary et al., (2009). Lower the technology index, higher is the feasibility of generated farm technology under farmers' fields and vice-versa. Similar results were also reported by Jeengar et al., (2006) in maize and Singh et al., (2017) in mustard.

\section{Economics analysis}

Highest gross returns of Rs. 43,484 ha ${ }^{-1}$, Rs. $35,656 \mathrm{ha}^{-1}$ of net returns and with $\mathrm{B}: \mathrm{C}$ ratio of 5.56 were recorded across the years for little millet under improved practices than under farmers' practices (Table.2). Highest gross returns Rs. 43,500 ha ${ }^{-1}$, Rs. 35,900 $\mathrm{ha}^{-1}$ of net returns with $\mathrm{B}: \mathrm{C}$ ratio of 5.72 were observed across the years for foxtail millet (Table 4).

The results of front line demonstration convincingly proved that the yield of turmeric could be increased yield with the better technological intervention. The grain yield under improved practices was recorded higher than the farmers' practices, which not only increased the yield per unit area but also enhanced the farmers' income.

However, a wide gap in potential yields, demonstration yields and farmers plot yields under both the crops due to technological and extension gaps indicating that there is a need of proper dissemination of location specific technologies imbedded with high yielding varieties to improve productivity and profitability in rainfed farming of Haveri District of north Karnataka. Therefore, FLD programme was effective in changing the knowledge of farmers towards improved/ recommended practices of little millet and foxtail millet. 


\section{References}

Choudhary A K, Yadav D S and Singh A, 2009, Technological and extension yield gaps in oilseeds in Mandi district of Himachal Pradesh. Indian Journal of Soil Conservation, 37(3): 224-229.

Dhaka B L, Meena B S and Suwalka R L, 2010, Popularization of improved maize production technology through frontline demonstrations in southeastern Rajasthan. Journal of Agricultural Sciences, 1(1): 39-42.

Dhruw, K.S., Sengar, R.S. and Yadav, K.N.,2012 Level of knowledge and adoption about recommended maize production technology. Agril. Update 7(3\&4): 311- 315

Jeengar K L, Panwar P And Pareek O P, 2006, Front line demonstration on maize in Bhilwada district of Rajasthan. Current Agriculture, 30(1/2): 115-116.

Saleh A S, Zhang Q, Chen J and Shen Q, 2013, Millet Grains: Nutritional Quality, Processing, and Potential Health Benefits. Food Science and Food Safety, 12: 281-295.

Samui S K, Mitra S, Roy D K, Mandal A K and Saha D, 2000, Evaluation of front line demonstration on groundnut. Journal of Indian Society of Coastal Agricultural Research, 18(2): 180-
183.

Singh S B, 2017, Impact of frontline demonstrations on yield of wheat (Triticum aestivum) under rain fed condition in Uttarakhand. International Journal of Science and Environmental Technology, 6(1): 779 $-786$.

Thakur A K, Kumar P. and Yadav S C, 2017, Impact of Front Line Demonstration (FLD) on the Yield and Economics of Small Millet on Bastar District of Chhattisgarh, India. International Journal of Current Microbiology and Applied Sciences, 6(9): 1489-1497.

Ushakumari S R, Shrikantan L and Malleshi N G, 2004, The functional properties of popped, flaked, extruded and roller dried foxtail millet (Setaria italica). International Journal of Food Science and Technology, 39: 907-915.

Vedna K, Kumar A, Kumar A and Bhateria S, 2007, Demonstration - an effective tool for increasing productivity of rapeseed- mustard in Kangra district of Himachal Pradesh. Himachal Journal of Agricultural Research, 33(2): 257-261.

Yadav R and Yadav V P, 2009, Harnessing productivity potential of small millets in Himalayan Hills. Indian Research Journal of Extension Education, 9(1): 62-64.

\section{How to cite this article:}

Ashoka. P., P. Priya and Sarojani J. Karakkannavar. 2020. Front Line Demonstration: A Technology Tool to Enhance the Millets Yield of North Karnataka. Int.J.Curr.Microbiol.App.Sci. 9(06): 2804-2811. doi: https://doi.org/10.20546/ijcmas.2020.906.339 